\title{
Testicular Sex Cord-Stromal Tumor
}

National Cancer Institute

\section{Source}

National Cancer Institute. Testicular Sex Cord-Stromal Tumor. NCI Thesaurus. Code C6358.

A benign or malignant tumor that arises from the testis. It is composed of granulosa cells, Leydig cells, Sertoli cells, and fibroblasts. Each of these cell types may constitute the only cellular component that is present in the tumor or it may be mixed with other cell types in various combinations. The prognosis can not always be predicted on histologic grounds alone. Approximately, ten percent of these tumors may metastasize.

Representative examples include granulosa cell tumor, Leydig cell tumor, Sertoli cell tumor, and tumors of the thecoma-fibroma group. 